\title{
ОБРАЗИ «НОВИХ ЛЮДЕЙ» У ПОВІСТІ «СЕМЕН ЖУК І ЙОГО РОДИЧІ» О. КОНИСЬКОГО
}

\author{
Надія Бойко
}

\author{
Кандидат філологічних наук, старший науковий співробітник, \\ Інститут літератури ім. Т. Г. Шевченка НАН України (УКРАЇНА), \\ 01001, м. Київ, вул. М. Грушевського, 4, \\ e-mail:nadia_bojko@ukr.net
}

\section{PЕФЕРАТ}

Мета статті - простежити концепцію творення образу «нових людей» в ідеологічній повісті «Семен Жук і його родичі» Олександра Кониського, проаналізувати мотиви їхнього екзистенційного вибору. Дослідницька методика. У розвідці поєднано біографічний, історико-генетичний та культурноісторичний підходи вивчення літературного явища. Результати дослідження. Ідеологічна проза О. Кониського дозволяє простежити еволюцію образу народника, «нової людини» в українській літературі другої половини XIX ст. - від зародження, набуття досвіду шляхом реалізації «малих справ», етап «культурного опору», розчарування і до самознищення. Поява в українській літературі ідеологічної повісті була закономірним процесом, зумовленим новими суспільними умовами, пошуком нового об'єкта художньої обсервації та функціями, які покладалися на неї: пропагування нових ідей і виховання покоління української інтелігенції. Ідеологічні повісті Кониського віддзеркалюють ідейно-світоглядні переконання самого автора, вони цінні як відтворенням подій «по гарячих слідах» (І. Франко), а й тим, як ці події сприймалися українським народником. Наукова новизна полягає у незаангажованому прочитанні ідеологічної прози другої половини XIX ст. як цілісного явища; осмисленні авторського задуму образу «нової людини». Практичне значення. Результати дослідження можуть бути використані для подальшого вивчення літературного процесу другої половини XIX ст., формозмістових особливостей української прози цього періоду; як додатковий матеріал при підготовці навчальних курсів, наукових семінарів і спецкурсів з історії української літератури.

Ключові слова. О. Кониський, українська проза, ідеологічна повість, жанр, образ, «нова людина», народник, Семен Жук.

\section{THE IMAGES OF «THE NEW PEOPLE» IN A NOVEL «SEMEN ZHUK AND HIS RELATIVES» BY OLEKSANDR KONYSKIY}

\author{
Nadiia Boiko \\ Ph.D. in Fhilology, Senior Researcher, \\ Shevchenko Institute of Literature of the NAS of Ukraine (UKRAINE), \\ 01001, Kyiv, 4, M. Hrushevskoho str., \\ e-mail: nadia_bojko@ukr.net
}

\begin{abstract}
Aim. The article deals with the image of a «the new people» described in an ideological novel «Semen Zhuk and his Relatives» by Oleksandr Konyskiy, and suggests an analysis of the ideas, according to which this image was created. Methods. The research is based on the biographical, historical and genetic, cultural and historical approaches to literature. Results. The ideological prose by O. Konyskiy allows one to trace the development of the image of «narodnyk»-a «new man»- in Ukrainian literature of the second half of the $19^{\text {th }}$ century. Thus, the evolution of a «new man» can be studied in a certain sequence: the emergence of a «new man», «small actions» taken by him his «cultural resistance», disillusionment and self-destruction. The appearance of the ideological novella in Ukrainian literature was a natural process resulting from new social conditions, the search for the new object of observation and the functions, which it had to fulfil (popularizing new ideas and bringing up
\end{abstract}


the conscious generation of Ukrainian intelligentsia). The ideological novels by O. Konyskiy reflect the ideological views and world outlook of their author. These works are valuable for describing the events without delay and showing the attitude of a Ukrainian narodnyk to them. The scientific novelty of the paper lies in a nonengaged view on Ukrainian ideological prose of the second part of the 19th century. The author of the article has considered the ideological prose as an integral phenomenon and studied the concept of a «new man». Practical meaning. The results of the research can be used for further studies of the literary process in the second part of the $19^{\text {th }}$ century and the peculiarities of the form and content of Ukrainian prose of this period. Furthermore, the study can provide additional information for the teachers of Ukrainian literature and students.

Key words: Oleksandr Konyskiy, Ukrainian prose, ideological novel, genre, image, "new man", narodnyk, Semen Zhuk.

Формування світогляду Олександра Кониського (1836-1900), становлення його як митця, публіциста і громадського діяча позначено впливом народницьких ідей. В ідеологічних творах він художньо реалізував концепцію народника, образ «нової людини», який був йому близький світовідчуттям i світорозумінням, частково акумулювавши в ньому свої сподівання, пріоритети діяльності та досвід культурного опору. Перші спроби прозаїка в цьому аспекті - оповідання «Пропащі люде» (1863) і «Перед світом» (1866) - не знайшли належної підтримки збоку критики через порушення важливого для реалістичної естетики критерію - відтворення «життя у формах життя»; на переконання М. Драгоманова, Кониський «забув перше правило живої белетристики - виводити на сцену існуючі, а не видумані особи й становища» [4, с. 268]. Повість-хроніку «Семен Жук і його родичі» (1875) можна розцінювати як своєрідний художній діалог із І. Нечуєм-Левицьким, зокрема 3 його повістю «Хмари» (1874), про що опосередковано може свідчити ставлення героїв повісті Кониського до народного одягу як важливого маркера (свій-чужий) належності до народницького руху, а в окремих сценах непряма полеміка 3 Радюком. Ще одним аргументом опосередкованого підтвердження висловленого припущення слугує розлога рецензія «Коли ж виясниться?» (1875), де Кониський підсвітив не питання естетики чи поетики твору, а зосередився на докладному аналізі образу головного героя, аргументуючи це тим, що хоч «без естетичного розвою можна огрубіти; але ще вірнійше, що самою чистою естетикою не можна розігнать тих темних хмар, котрі повисли над нашою громадою...» $[5$, с. 368]

Постановка проблеми. Ідеологічну прозу Кониського розглядаємо як явище літературного проектування, зумовлене насамперед позакультурними чинниками. 3 цього погляду повість-хроніка «Семен Жук і його родичі» викликає дослідницький інтерес, оскільки дозволяє простежити особливості розгортання народницького руху в Україні в 1850-1860-х рр. в рецепції одного 3 його багаторічних учасників, проаналізувати програмовий підхід до концептування образу «нової людини» та популяризації ї̈ діяльності.

Аналіз останніх досліджень і публікацій: Становлення української інтелігенції, їі взаємодія із селянською верствою перебуває у центрі наукових зацікавлень, насамперед це стосується історичної галузі, де тільки протягом останнього десятиліття з'явилася низка грунтовних досліджень. Одночасно в літературознавстві відбувається поглиблене осмислення ідей народництва й позитивізму як невід'ємних чинників літературного процесу другої половини 
XIX ст., їх вплив на формування філософсько-естетичного мислення письменників, розвиток літературно-критичної думки, зрештою на поетику творів. Ці та інші питання були об'єктом наукових розвідок Т. Гундорової, Н. Зборовської, В. Моренця, С. Павличко, Н. Шумило тощо. Досі актуальні дискусії щодо ролі народництва в українській культурі, які зчаста зводяться до різкого його протиставлення модернізму. С. Павличко, досліджуючи становлення українського модернізму, хоч і пов'язувала його появу із кризою ідей народництва, проте наголошувала народництво як «центральний термін української інтелектуальної історії» <..> народництво [що стало] способом художнього існування літератури, стилем або системою стилів» [14, с. 27]. Заперечуючи модерністське зречення всього питомо національного, В. Моренець зауважує, що «„народництво”» саме собою не виробило нічого гальмівного для подальшого поступу українського письменства, для якого власна етнокультурна й психолінгвістична база $<\ldots>$ була, $\epsilon$ і буде визначальною» $[12$, с. 52]. Народництво як один із модернізаційних проектів в інтерпретації Т. Гундорової був «не зовсім органічним явищем саморозвитку української культури, а свідомим проєктом, що його послідовно розробляла українська інтелектуальна еліта» $[6$, с. 74]. Під аналогічним кутом зору проаналізовано українську прозу другої половини XIX ст. [2; 3]. У низці сучасних літературознавчих досліджень акцентуються жанротворчі, проблемно-тематичні й образотворчі особливості ідеологічної прози. В. Панченко, простежуючи генезу соцреалізму крізь призму ідеологічної прози другої половини XIX ст., серед іншого виокремив найхарактерніші ऑii складники: дидактично-публіцистичний первень, позитивний герой-народолюбець, контрастне змалювання персонажів і соціальний детермінізм $[13$, с. 60,61$]$. Відверта тенденційність реалістичної прози зазначеного періоду, як i охудожнення культурно-просвітницької концепції відповідали «потребам часу, <...> визначали їі історичний обсяг» $[11$, с. 23]. 3-поміж художньо-стильових ознак ідеологічної прози увиразнюється передусім «розлогий публіцистичний виклад суспільно-політичних тенденцій описуваної епохи <..> змалювання інтелігентів-просвітників крізь національно-психологічну призму» $[2$, с. 75,79$]$.

Виклад основного матеріалу. 1873 року Кониський розпочав роботу над повістю-хронікою «Семен Жук і його родичі», перші дві їі частини з'явились у галицькій «Правді» протягом 1875 року, проте твір так і залишився невикінченим. 1876 року першу редакцію третьої частини повісті прозаїк передав до Львова через знайомого, але під час перевірки на прикордонній станції Волочиськ рукопис було втрачено. Оскільки І. Белей планував видати цей твір у «Бібліотеці найзнаменитіших повістей», звертався до Кониського 3 проханням якнайшвидше подати іiі закінчення. У лютому 1884 року автор інформував видавця про завершення роботи над трьома главами третьої частини та висловлював готовність дослухатися до ймовірних його зауважень. Видавничий процес затягнувся через суперечки з автором; Белей зрештою не квапився видавати повість, вважаючи необгрунтованими запропоновані сюжетні лінії, насамперед пов'язані з Рисею Жук, якій відводилася головна роль у фінальній частині повісті. 
Об'єктом художньої рецепції в повісті стала ідейна й моральна диференціація покоління української інтелігенції 1860-1880-х рр., що Кониський проілюстрував образами Семена Жука й Антона Джура. Про майбутні життєві перипетії прозаїк натякає вже у зачині твору, де невипадково акцентує поріг, на якому сидять товариші, поріг, що відділяе їх від уже минулого студентського безтурботного життя і стає відправною точкою у нове; героям потрібно вибрати свою життєву дорогу, щоб стати корисним суспільству. Тематичну новизну й актуальність повісті «Семен Жук і його родичі» навіть у незавершеному варіанті визнавали тогочасні дослідники, адже вона «торкала питання свіжі актуальні і в хаосі тодішніх суспільних думок могла й подавати галицьким народовцям деяку синтезу громадянської діяльності» $[1$, с. 6].

Необхідність створення концепції «нової людини» поставала з особистого досвіду громадської і просвітницької діяльності Кониського. Відходив у минуле фольклорно-етнографічний етап народницького руху, молодь 1860 1870-х рр. шукала підтримки своєї ініціативності, швидко розчаровувалася не отримавши і1і. Чіткими штрихами Кониський прокреслив настрої молоді 1850-х i 1860-1870-х років, вказавши на деградацію намірів: «в гімназиях були «центри», коло котрих груповалась молодіж; <..> націоналів, космополітів, идеалістів, реалістів <..> розвивалась молодіж. Герценовский «Колокол», твори Бюхнера, Файербаха не то що читались, а виучувались на пам'ять», але кипуча і продуктивна діяльність звелася до театральності (носіння одягу селянського), обернулася на вигоду, «на поле акціонерне, процентове, на поле легкої наживи, через що другі ниви життя зостались перелогами» [7, с. 133]. Тож повість можна розглядати як своєрідний конспект-ілюстрацію для молодих ентузіастів громадської роботи.

Концепція «нової людини» хоч і належить епосі романтизму, проте вже в другій половині XIX ст. вона видозмінилася, ставши невід'ємною ланкою культурно-просвітницького руху. Зазвичай йдеться про представника поміщицького (чи шляхетського) стану, що усвідомив свій «гріх» - незнання, байдужість, віддаленість від національно-культурного життя своїх співвітчизників із нижчого суспільного прошарку, і що своїм «осілим» народолюбством чи економічними «малими справами» прагне «спокутувати гріхи», підвищивши культурно-освітній рівень чи покращивши матеріально-господарське становище селянства. Авторське бачення «нової люди» нерозривно пов'язане з таким набором якостей, як світоглядна зрілість, альтруїзм, щирість, доброта й розважливість. Концепція не передбачала відірваності «нової людини» від соціуму; вона не почувається зайвою; не схильна до революційних закликів, бо не бачить сенсу жертвувати своїм життям, навпаки, свої зусилля спрямовує на розбудову. Поява «нових людей» супроводжувалася конфронтацією, бо їм доводилося конфліктувати із системою, частиною якої були, а отже, поставала необхідність зректися минулого й розпочати нове життя. Історія засвідчує чимало подібних випадків, найвідоміші - В. Антонович, Т. Рильський, пізніше Б. Грінченко та С. Русова. А втім, інколи такі шляхетні експерименти не давали бажаного результату, і як спостеріг С. Єфремов: «Більше просто одходило мовчки, -3 тих, хто менше цікавився громадськими справами й нетвердо 
засвоїв самі принципи українства, - дичавіло, опускалось і робилось звичайними сільськими обивателями. I тільки меншість підтримувала повсякчасні зносини і зв'язки» [8, с. 151].

Протагоніст повісті Семен Жук постає як сформована особистість. Автор підсвічує внутрішню колізію: Семен - поміщицький спадкоємець, здобувши диплом правника, відмовляється від перспективної кар'єри судовика чи адвоката. Як натура романтична аморальним й антигуманним вважає суд над людиною, що оступилася через матеріальну скруту. Попри іронічні закиди його товариша Джура в маніловщині й відсутності досвіду господарювання, Семену все ж таки більш продуктивним видається шлях господарсько-економічної допомоги односельцям. Кониський відкидає «культурний маскарад» (Т. Гундорова) Радюка, адже Семен Жук як «нова людина» обирає більш прикладний аспект діяльності: «тілько працювать, учить ділом і давать пораду тілько тогді, як у мене питатимуть»; категорично не бажає наслідувати «романтичних» народолюбців: «Не носитиму я народного убрання, заігрувать 3 мужиком не буду...» [7, с. 13]. Не нав'язування своєї програми дій та не загравання із селянами розраховані як довгостроковий та ефективний проект, дозволяють Семену більше зблизитися з ними, довести свою щирість, а головне - показати результативність «малих справ» на селі. Жук намагається діяти 3 позиції «м’якої сили», як, наприклад, із небажанням селян організувати школу.

Жук один із тих літературних типів-народників, що перебуває у стані душевної гармонії, чинить правильно, за це доля винагороджує його відданими друзями й хорошою родиною. Характер і світогляд Семена розкриваються у численних розмовах i дискусіях, зрозумілішими стають його пріоритети як духовні (роль пісні і поезії в житті людини), так і більш практичні, наприклад, роль жінок у суспільстві та необхідність університетської освіти для них. Жук критично відгукується про освіту, зокрема університетську, бо вона мала б зміцнювати не тільки інтелектуально, а й що найважливіше - духовно, однак «наша професура - се стара каліч, напоєна <..> духом користи, егоїзму, бюрократизму...» [7, с. 179]. Щодо цих питань, загалом герой проголошує відомі тези самого Кониського, які зустрічаються у його численних публіцистичних статтях, однак не відображає авторське Я.

До речі, виразник авторських ідей, зразок українського інтелігента поміщик Віренко, в характері і поглядах якого простежують автобіографічні риси. Він 3 «нових людей» покоління 1850-х, переживши політичні переслідування і заслання, оселяється на хуторі, але не полишає боротьби з бюрократією. Кониський відводить йому роль тихого й мудрого наставника Семена $\mathrm{i}$ Рисі, якого так не вистачало молодому Радюку («Хмари» Нечуй-Левицький), на що й звертав увагу рецензент. Саме Віренко розвіює романтизм молодого Жука, бо «однією піснею, однією поезією нічого не вдієш! < ..> пісня і поезія підіймають духа, енергію, патріотизм, підіймають духовне житє <..> але треба спершу діло робить <..> Самі ви добре знаєте, що чоловік голодний і холодний не співатиме» $[7$, с. 339].

Інший психотип Кониський репрезентував в образі молодого лікаря Антона Джура, що походив зі збіднілого шляхетського роду. За задумом 
Кониського цей образ - хрестоматійна ілюстрація моральної деградації продуктивних молодих сил покоління 1870-х, коли гору взяли меркантилізм, а прихильність до нових ідей грунтується на тезі «ubi bene, ibi patria». Їх письменник характеризував доволі різко, порівнюючи 3 деревом, що «росте на грунті того «нового духу», котрий тогді тілько що подавав свої міязми, а в тих міязмах багацько задушилось людей, i ще більше гарних речей про волю i освіту - перемінились на короткі, незвучні, але корисні слова: акція, облігація, банк, дивіденда, гроші!» [7, с. 134]. Попервах, незважаючи на незначні розбіжності між давніми товаришами щодо подальшого професійного заняття, прозаїк не позиціонував Антона як антагоніста, навпаки, показує його більш реалістичним і розважливішим, на відміну від романтичного Семена. Навіть більше, саме Антон безкорисно взявся допомогти хворій та самотній бабусі. Та поступово Кониський згущує негативні риси в характері й поведінці Антона, все очевиднішим стає контраст із Семеном. Фінансовий чинник домінує у романтичних стосунках Антона із Рисею, що було зумовлено страхом малозабезпеченого майбутнього його як лікаря, а втім, поступово антагоніст дегуманізується і навіть після виграшу значної суми, живе за рахунок Уляни Лаврової, занехаявши почуття до Рисі. Авторські звинувачення надто різкі, а покарання надто прямолінійне: досягнувши кар'єрної і фінансової вершини, Антон втратив здоров'я.

Кониський-публіцист, наголошуючи вплив української жінки на чоловіка та іiі роль у вихованні покоління, висновував необхідність заснування жіночих шкіл, бо «українська дворянка і багата купчиха тепер чисте лихо в Україні, щирий ворог усього українського. Вона більше од мужчини ненавидить усе українське і цурається його, як чорт ладану, вигонить його із сім'ї, з дому, перекручує прислугу так само, як і польська пані» [10, с. 567]. У рецензії «Коли ж виясниться?» роздуми про спільну («гуртову») працю на користь народу, автор завершує закликом: «треба, щоб на запомогу «ченцям» [народникам $H$. Б.] вийшли наші женщини і внесли в свої сем'ї, в вихованє своїх дітей справжні національні і економічні основи» [5, с. 371]. Уникаючи протиставлення «батьки - діти», «сильний чоловік - слабка жінка», прозаїк репрезентував жіночі психотипи, поведінка яких детермінована соціальними обставинами.

Найбільш патріархальним у галереї образів $є$ Жучиха, життя якої підпорядковано створенню атмосфери родинного спокою; за щирість, доброту i розважливість іiі шанують сусіди-поміщики; вона вибудовує добросусідські стосунки із селянами, а ті на знак вдячності щоразу сходяться до неї на толоку. Як бачимо, Кониському вдається уникнути не тільки соціального, а й міжпоколіннєвого конфлікту, адже попри свій вік Жучиха підтримує новітні захоплення дітей, що особливо помітно на прикладі ставленні до Рисі після іiі повернення 3 Цюріха. У рамки традиційної парадигми жіночих образів вкладається і образ Соні - добра і хазяйновита, як і iї матір, проте здобула домашню освіту; музика і читання стають невід'ємною частиною іiі життя. Ба більше, Соня - це радше deus ex machina у творі. Вочевидь прозаїк задля пожвавлення читацького інтересу й розгорнув лінію кохання «сестри і брата», Соні і Семена, однак ця інтрига не набула належної гостроти, а їхнє одруження 
- винагорода долі за шляхетні вчинки. Цікаво, що прозаїк не змалював іiі красунею, натомість акцентував іï розумовий потенціал: «чорні як ніч и блискучі як зірки очи служили зеркалом <..> розуму <..> хто довгенько дивився на Соню, одходячи од неї дума: король-дівка!» [7, с. 50-51].

Справді новаторським у тодішній українській прозі і насамперед у доробку самого Кониського став образ Рисі Жук, «нової людини», поданий у динамічному розвитку, а втім з об'єктивних причин не зреалізований до кінця. У цьому образі прозаїку вдалося втілити найсміливіші задуми, що до певної міри були суголосні ідеям позитивізму. Рися - освічена, амбіційна, емансипована, прагне професійного розвитку й активної діяльності. Ї̈ї світогляд i риси характеру щонайперше підсвічуються у дискусіях, особливо коли ті стосуються ролі жінки у суспільстві чи права їі на освіту: «Не можна й не сердиться, коли чуєш, як розумний чоловік, чоловік освічений, чоловік, котрий видає з себе ліберала, стане верзти отаке» [7, с 177]. Вона переконана, що жінкам треба дати рівноцінні з чоловіками можливості, бо «Хиба ж таки ваші університети заведені на приватні, на зібрані гроші?» <..> як по-вашому зробить тогді, коли вчиться в університеті показалась хіть у таких тілько дівчат, котрі убогі, не мають спроміжності» [7, с 177]. Швидке дорослішання i становлення Рисі як цільної особистості Кониський подав крізь призму ії кохання до Антона Джура, що поступово змінюється від глибокого емоційного захоплення до усвідомлення, що через діаметрально протилежні світоглядні переконання вони ніколи не стали б справжнім подружжям. Життя і навчання за кордоном утвердило Рисю у правильності іiі життєвого вибору, вона, як і Люба Калиновська (Олена Пчілка «Товаришки», 1887), здобуває медичну освіту, повертається в Україну і прагне допомагати людям, бо «рівняла житє селян на Україні до життя селян за кордоном. Не стояв перед iï очима на Україні той страшенний пролетаріят, котрий вона бачила за кордоном, але ще страшнійше его стояла темнота и убожество украінских селян» [7, с. 872].

Висновки. На українську ідеологічну прозу як складник літературного народництва покладалася утилітарна функція - пропагування нових ідей, виховання і популяризація образу «нової людини» - альтруїстичного представника української інтелігенції чи поміщицтва.

Жанр повісті-хроніки посприяв створенню широкомасштабної картини суспільного життя на значному часовому відрізку. Попри емоційно-чуттєве змалювання, образ народника, як і повороти його долі, не $є$ типовими, ні індивідуальними; його характер та ідейні переконання увиразнюються у конфліктних ситуаціях і дискусіях. Художньо-образна система повісті «Семен Жук i його родичі» структурована за принципом контрастно-попарного життєпису, адже 1860-1870-ті pр. породили не тільки «нових людей», що прагнули практичної праці на користь селянству, але час «економічного добробиту» зумовив появу не менш виразних псевдонародників і фразерів, що дбали про власну вигоду.

\section{ЛІТЕРАТУРА}

1. Авдикович О. Огляд літературної діяльності Олександра Кониського. Перемишль, 1908. $127 \mathrm{c}$. 
2. Бойко Н. Ідеологічна проза другої половини XIX ст. крізь призму ідеологічну. Слово $i$ Чac. 2015. № 1. С. 72-82.

3. Бойко Н. Проза другої половини XIX ст. як літературне проектування. Українська література XIX - початку XX cm.: художне слово у поступі нації : наук. збірник / НАН України. Інститут літератури ім. Т. Г. Шевченка, К., 2014. С. 162-181.

4. Драгоманов М. Листи на Наддніпрянську Україну. Літературно-публіцистичні прац̧і: у 2 $m$. Київ : Київський поліграфічний комбінат, 1970. Т. 1. 531 с.

5. Історія української літературної критики та літературознавства. Хрестоматія : у 3 кн. / упор. П. Федченко. Київ : Либідь, 1996. Кн. 1. 416 с.

6. Гундорова Т. ПроЯвлення Слова. Дискурсія раннього українського модернізму. Київ : Критика, 2009. 447 с.

7. Яковенко (Кониський О.) Семен Жук і його родичі. Правда. 1875. № 1-10, 16-20, 22.

8. Єфремов С. Про дні минулі (Спогади). Молода нація. 2003. № 1(26). С. 134-191.

9. Кониський О. Перед світом. Русалка. 1866. № 6-11.

10. Кониський О. Украінский націоналізм. Правда. 1875. Ч. 14. С. 566-572.

11. Ковалів Ю. Історія української літератури кінець XIX - початок XXI ст. : у 10 т. Київ : ВЦ «Академія», 2013. Т. 2. 624 с.

12. Моренець В. Національні шляхи поетичного модерну першої половини XX ст. : Україна i Польща. Київ : Основи, 2001. 327 с.

13. Панченко В. Ідеологічна повість II половини XIX ст. і генеза соцреалізму. Слово $i$ Час. 2011. № 2. С. 58-63.

14. Павличко С. Дискурс модернізму в українській літературі. Київ : Либідь, 1999. 447 с.

\section{REFERENCES}

1. Avdykovych, O. (1908), A review of the literary activities of Oleksander Konyskiy [Ohliad literaturnoi diialnosti Oleksandra Konyskoho], Peremyshl, 127 p. (in Ukrainian).

2. Boiko, N. (2015), "Fiction writing of the second half of the 19th century and the national identity" ["Ideolohichna proza druhoi polovyny $19^{\text {th }}$ st. kriz pryzmu ideolohichnu"], Slovo $i$ Chas, No. 1, pp. 72-82. (in Ukrainian).

3. Boiko, N. (2014) "The prose of the second half of the 19th century as literature's project", Ukrainian literature of the 19th and early 20th century: an artistic word in the nation's progress ["Proza druhoi polovyny 19 st. yak literaturne proektuvannia", Ukrainska literatura 19 - pochatku 20 st.: khudozhnie slovo u postupi natsii: nauk. zbirnyk], Kyiv, pp. 162-181. (in Ukrainian).

4. Drahomanov, M. (1970), "The letters to the Dniper's Ukraine", Literary and journalistic works: 2 vols. Vol. 1 ["Lysty na Naddnipriansku Ukrainu", Literaturno-publitsystychni pratsi u 2 t. T. 1], Kyivskyi poligrafkombinat, Kyiv, 531 p. (in Ukrainian).

5. Fedchenko, P. (Comp.). (1996), A history of Ukrainian literary criticism and literary studies. Reader: in 3 books. B. 1. [Istoriia ukrainskoi literaturnoi krytyky ta literaturoznavstva. Khrestomatiia: $u 3$ kn. Kn. 1], Lybid, Kyiv, 416 p. (in Ukrainian).

6. Hundorova, T. (2009), The Emerging Word. The Discourse of Early Ukrainian Modernism [ProIavlennia Slova. Dyskursiia rannoho ukrainskoho modernizmu], Krytyka, Kyiv, pp. 447. (in Ukrainian).

7. Iakovenko (Konyskyi, O.). (1875), "Semen Zhuk and his relatives" ["Semen Zhuk i yoho rodychi"], Pravda, No. 1-10, 16-20, 22. (in Ukrainian).

8. Iefremov, S. (2003), "About last days. (Memoirs)" ["Pro dni mynuli (Spohady)"], Moloda natsiia, Kyiv, No. 1(26), pp. 134-191. (in Ukrainian).

9. Konyskyi, O. (1868), "Dawning" ["Pered svitom"], Rusalka, No. 6-11. (in Ukrainian).

10. Konyskyi, O. (1875), "Ukrainian nationalism" ["Ukrainskyi natsionalizm”], Pravda, No. 14, pp. 566-572. (in Ukrainian).

11. Kovaliv, Yu. (2013), History of Ukrainian literature at the end of XIX - the beginning of XXI century in 10 vols. Vol. 2. [Istoriia ukrainskoi literatury kinets 19 - pochatok 20 st.: u 10 t. T. 2], 
Akademiia, Kyiv, 624 p. (in Ukrainian).

12. Morenets, V. (2001), National paths of the poetic modernism in the first half of the $20^{\text {th }}$ century: Ukraine and Poland [Natsionalni shliakhy poetychnoho modernu pershoi polovyny 20-st.: Ukraina i Polshcha], Osnovy, Kyiv, 327 p. (in Ukrainian).

13. Panchenko, V. (2011), "Ideological narratives of the second half of the 19th century and the genesis of socialist realism" ["Ideolohichna povist II polovyny 19-st. i heneza sotsrealizmu"], Slovo i Chas, No. 2, pp. 58-63. (in Ukrainian).

14. Pavlychko, S. (1999), The discourse of the modernism in Ukrainian literature. [Dyskurs modernizmu v ukrainskiy literaturi], Lybid, Kyiv, 447 p. (in Ukrainian).

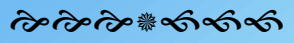

